\title{
Experimental pulmonary embolism by platelet agglutinates in dogs
}

\author{
ROBERT MARSHALL AND M. S. DUNNILL \\ From the Nuffield Department of Surgery and the Department of Pathology, Radcliffe Infirmary, Oxford
}

It is probable that small fibrin thrombi are constantly being formed in the venous system and become impacted in the lungs. The lungs of dogs are able to lyse several hundred millilitres of fresh blood clot injected into the venous system over a period of months and the animals' pulmonary arterial pressure remains normal (Marshall and Allison, 1962). Small emboli may, however, be composed of the formed elements of the blood such as platelets and leucocytes, and these emboli may be less susceptible to lysis and more able to produce a cumulative effect resulting in pulmonary hypertension.

The present study was made to investigate the immediate physiological effect and the ultimate pathological effect of repeated pulmonary embolism by platelet agglutinates in dogs.

\section{METHODS}

The experiments were carried out on 12 dogs, premedicated with $1 \mathrm{mg}$. $/ \mathrm{kg}$. morphine and anaesthetized with pentobarbitone. Short-term experiments were made on seven dogs. Four dogs received only one injection of platelet concentrates, which was prepared from 0.9 to 1.7 litres of the blood from a donor dog, and the platelets were agglutinated with serum from the donor dog. In three dogs (dogs 5,6 , and 7) 50 to $100 \mathrm{ml}$. of autologous blood was used to prepare the platelet concentrate, and adenosine diphosphate (ADP) in a final concentration of $100 \mu \mathrm{g} . / \mathrm{ml}$. was used to agglutinate them. Dog 5 received two injections of platelet concentrate with an interval of seven days and was killed shortly after the second injection; dog 6 received one injection and was killed shortly afterwards, and $\operatorname{dog} 7$ was killed six days after a single injection.

After death the lungs were fixed by intravenous infusion of the dog with formol saline. Several hours later the lungs were removed from the thorax and fixation was continued in a bath of formol saline. The same procedure was used for the dogs studied in the long-term experiments.

Five dogs were used in the main experiment to investigate the effect of repeated injections of platelet emboli. Blood was withdrawn by puncture of the femoral vein. Twenty millilitres was used for the preparation of serum and $80 \mathrm{ml}$. was added to $8 \mathrm{ml}$. of $4.5 \%$ sodium ethylene diamine tetracetate (EDTA) in nylon tubes. These tubes were centrifuged at 1,000 r.p.m. for $15 \mathrm{~min}$. for separation of the plateletrich plasma, and this plasma was then centrifuged at 3,000 r.p.m. for $15 \mathrm{~min}$. to sediment the platelets. The platelets were washed twice by resuspending them in normal saline and centrifuging and were finally suspended in about $3 \mathrm{ml}$. saline. In some of the later experiments of the series the platelets were suspended in $10 \mathrm{ml}$. saline; $1 \mathrm{ml}$. of this suspension was retained for platelet count and serotonin assay and the remainder was centrifuged and resuspended in $3 \mathrm{ml}$. saline. Siliconized glassware was used throughout.

The platelets were agglutinated by the addition of about $7 \mathrm{ml}$. serum followed by gentle agitation of the tube. Agglutination of the platelets with the production of visible flocculates occurred usually in onehalf to two minutes. The agglutinated suspension was transferred to a syringe and injected through an indwelling thin-walled 18 gauge needle, usually into a hindleg vein on the side opposite to that from which the blood had been taken. At the end of each experiment the red cells and the remainder of the plasma were reinjected into the dog.

Injections of platelets were given to each of the five dogs at approximately weekly intervals for 43 , $42,29,27$, and 14 doses, respectively. Before the start of the series of injections measurements of functional residual capacity (F.R.C.) were made using a closed-circuit helium method. The diffusing capacity of the lungs for carbon monoxide ( $\left(\mathrm{LL}_{00}\right)$ was measured using a single breath method as described previously (Marshall, Sabiston, Allison, Bosman, and Dunnill, 1963). After the dog had breathed $100 \%$ oxygen for five minutes simultaneous end-tidal gas and arterial blood samples were taken. The carbon dioxide tension $\left(\mathrm{PCO}_{2}\right)$ and oxygen tension $\left(\mathrm{PO}_{2}\right)$ of the samples were measured using a Severinghaus electrode and a Clark electrode, and from these results the end-tidal arterial $\mathrm{PCO}_{2}$ difference and the right-to-left shunt of venous blood were calculated (Marshall et al., 1963). The pulmonary arterial pressures were measured by catheterization via the jugular vein; the reference level was the highest part of the sternum with the dog supine. In two of the dogs catheteriza- 
tion was repeated after 10 injections of platelets, but intermediate catheterization was not carried out in the other dogs because of the need to conserve veins.

The tidal volume and intra-oesophageal pressure were recorded continuously, and from these records measurements of compliance and non-elastic resistance of the lungs were made as described previously (Marshall and Allison, 1962).

During the course of the experiment the following variations in procedure were used:

ANOXIA Since the response to platelet emboli was small and variable whilst the dog was breathing a high oxygen mixture, the effect of anoxia, such as might exist in patients, was also investigated. The spirometer circuit was filled with an air-nitrogen mixture containing about 6 to $8 \%$ oxygen. The dog, breathing air, was connected to the circuit, and pure oxygen was added to keep the spirometer tracing level. The oxygen concentration in the circuit was again analysed at the end of the experiment.

DRUGS The effect on respiration and lung mechanics of small doses of serotonin and histamine was observed, both when the dog was breathing a high and a low oxygen mixture. The intention was to compare the effect of these drugs with the response to platelet emboli. Serotonin creatine phosphate was given intravenously in doses of 100 and $200 \mu \mathrm{g}$. in a volume of $5 \mathrm{ml}$. The usual dose of histamine acid phosphate was $50 \mu \mathrm{g}$. in $5 \mathrm{ml}$., but in some dogs injections of $100 \mu \mathrm{g}$. in $10 \mathrm{ml}$. were also given.

SEROTONIN INFUSION An intravenous infusion of 90 to $120 \mathrm{mg}$. serotonin creatine phosphate given over 60 to 90 minutes was used in order to increase the serotonin content of the platelets (Weissbach, Bogdanski, and Udenfriend, 1958). One hour after the end of the infusion the dogs were bled and the platelets separated in the usual way.

RESERPINE Reserpine was used to deplete the platelets of serotonin (Haverback, Dutcher, Shore, Tomich, Terry, and Brodie, 1957 ; Shore, Pletscher, Tomich, Carlsson, Kuntzman, and Brodie, 1957). A single dose of $40 \mathrm{mg}$. reserpine was given to two of the dogs 16 hours before withdrawal of the blood. This produced satisfactory reduction of the serotonin content of the platelets, but the effect on respiration and on the general condition of the dogs was so great that the dose was reduced to $10 \mathrm{mg}$. for the other two dogs.

In some of the later experiments the serotonin content of the platelets was assayed on rat colon at $25^{\circ} \mathrm{C}$. by the method of Humphrey and Toh (1954). Before assay the platelets were lysed by freezing and thawing three times.

\section{RESULTS}

SHORT-TERM EXPERIMENTS The four dogs which received platelets from donor dogs were killed 2 , 4,5 , and 7 days respectively after the injection of
T A B L E I

RESPONSE TO INJECTIONS OF PLATELETS FROM A DONOR DOG

\begin{tabular}{|c|c|c|c|c|c|}
\hline \multirow{2}{*}{$\begin{array}{l}\text { Dog } \\
\text { No. }\end{array}$} & \multirow{2}{*}{$\begin{array}{c}\text { Vol. of } \\
\text { Suspension } \\
\text { (ml.) }\end{array}$} & \multirow{2}{*}{$\begin{array}{c}\text { Change in } \\
\text { Respira- } \\
\text { tion }^{1}\end{array}$} & \multicolumn{2}{|c|}{$\underset{\text { (mm. Hg) }}{\text { Pulmonary Art. Press. }}$} & \multirow{2}{*}{$\begin{array}{c}\text { Compliance } \\
\text { Decrease } \\
(\%)\end{array}$} \\
\hline & & & Before & After & \\
\hline $\begin{array}{l}1 \text { (a) } \\
2 \text { (b) } \\
3 \text { (a) } \\
4 \text { (b) }\end{array}$ & $\begin{array}{l}15 \\
15 \\
20 \\
14 \\
14 \\
10\end{array}$ & $\begin{array}{l}+ \\
0 \\
0 \\
\pm \\
\pm \\
0\end{array}$ & $\begin{array}{l}10 / 3 \\
15 / 8 \\
5 / 0 \\
7 / 0 \\
20 / 5\end{array}$ & $\begin{array}{c}26 / 29 \\
23 / 13 \\
11 / 3 \\
11 / 1 \\
30 / 13\end{array}$ & $\begin{array}{r}70 \\
0 \\
-0 \\
0 \\
-\end{array}$ \\
\hline
\end{tabular}

platelets. The yield of platelets from the blood was not measured; it was particularly good in $\operatorname{dog} 3$ and poor in $\operatorname{dog} 4$. The results are summarized in Table $I$. In two of the dogs the respiration became more rapid and shallow, but in only one of these was the effect marked, and the other two dogs showed no change in respiration. Transient increases in pulmonary arterial pressure also occurred after the injections.

The three dogs which received platelet agglutinates derived from 50 or $100 \mathrm{ml}$. of their own blood and agglutinated with adenosine diphosphate showed no appreciable change in respiratory pattern, pulmonary arterial pressure, or lung compliance. A control injection of adenosine diphosphate caused a considerable tachycardia but with a rise of pulmonary arterial pressure of only 1 or $2 \mathrm{~mm}$. $\mathrm{Hg}$.

Examination of the gross lung specimens was not very rewarding. A few focal areas of congestion were present, usually in the lower lobes. The cut surface of the fixed lungs showed a few small non-occluding masses to be present in the smaller conducting pulmonary arteries.

Histology of the lungs in dog 6, killed on the same day as the platelet emboli were given, revealed small non-occluding masses in the muscular arteries and arterioles (Fig. 1). These masses were eosinophilic, often with a slightly vacuolated appearance, and contained a very occasional mononuclear type cell. Their staining reactions indicated that only a little fibrin was present; they were periodic-acid-Schiff-positive and stained positively using the method of Carstairs (1965). There was no reaction in the periarterial tissues, but this was not surprising in view of the fact that the dog died within two or three hours of receiving the emboli. No embolic material was seen in the larger conducting arteries.

Dog 1 was killed two days after donor platelet emboli had been administered. The appearances in the muscular pulmonary arteries were remark- 
FIG. 1. Dog 6. Small, nonoccluding platelet emboliadherent to the wall of a muscular pulmonary artery. Periodic acid Schiff, $\times 400$.

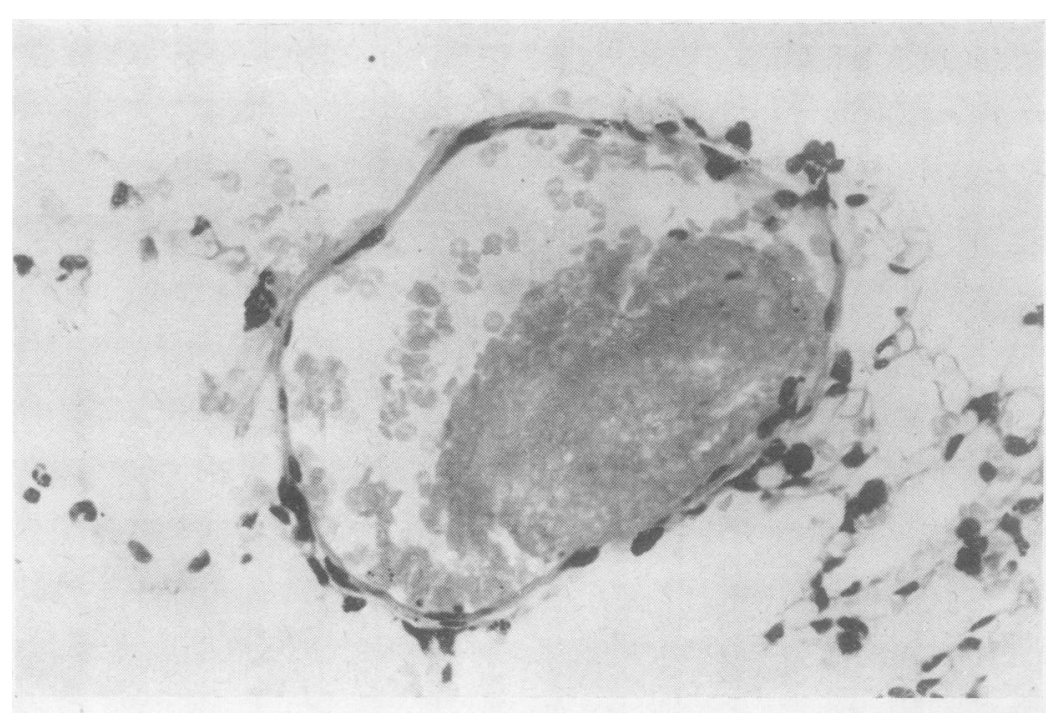

ably similar to those seen in $\operatorname{dog} 6$, apart from the fact that the emboli were smaller. No perivascular reaction was present. The main changes in these lungs were in the conducting vessels, where large, often occluding, masses of homogeneous eosinophilic material could be seen (Fig. 2). Often this material had lodged at the bifurcation of vessels. No organization had started. These appearances contrast with those seen in experiments in which blood clot or thrombus is used, or in human pulmonary embolism where the adventitial reaction, with focal dilatation of the vasa vasorum, can be seen within 24 to 48 hours of embolization.
Dog 2, killed four days after embolization with donor platelets, showed no material in the muscular pulmonary arteries. In the conducting pulmonary arteries the emboli were attached firmly to the arterial wall. The vasa vasorum in the adventitia were dilated, and a few plump endothelial type cells were present over the surface of the homogeneous embolic mass. The mass itself stained strongly positive with the periodic-acidSchiff method.

In $\operatorname{dog} 4$, seven days after embolization, organization at the point of attachment of the embolus to the arterial wall was well advanced (Figs 3 and 4). The vasa vasorum were apparently

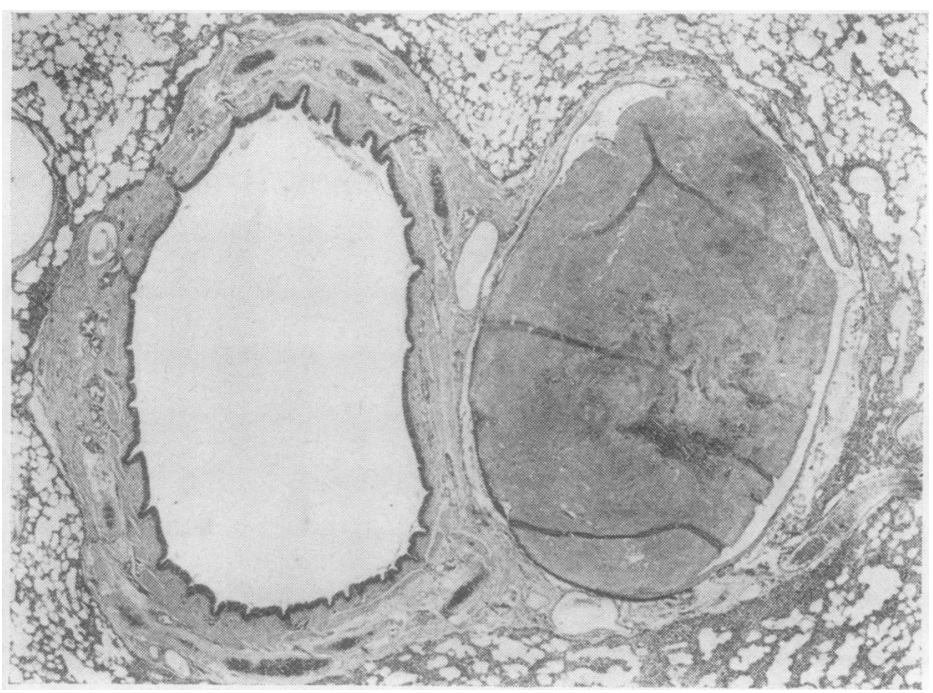

FIG. 2. Dog 1. Shows a conducting pulmonary artery occluded by a platelet agglutinate. Haematoxylin and eosin, $\times 15$. 
FIG. 3. Dog 4. Shows masses firmly attached to the arterial wall at a bifurcation seven days after embolization. Haematoxylin and eosin, $\times 33$.
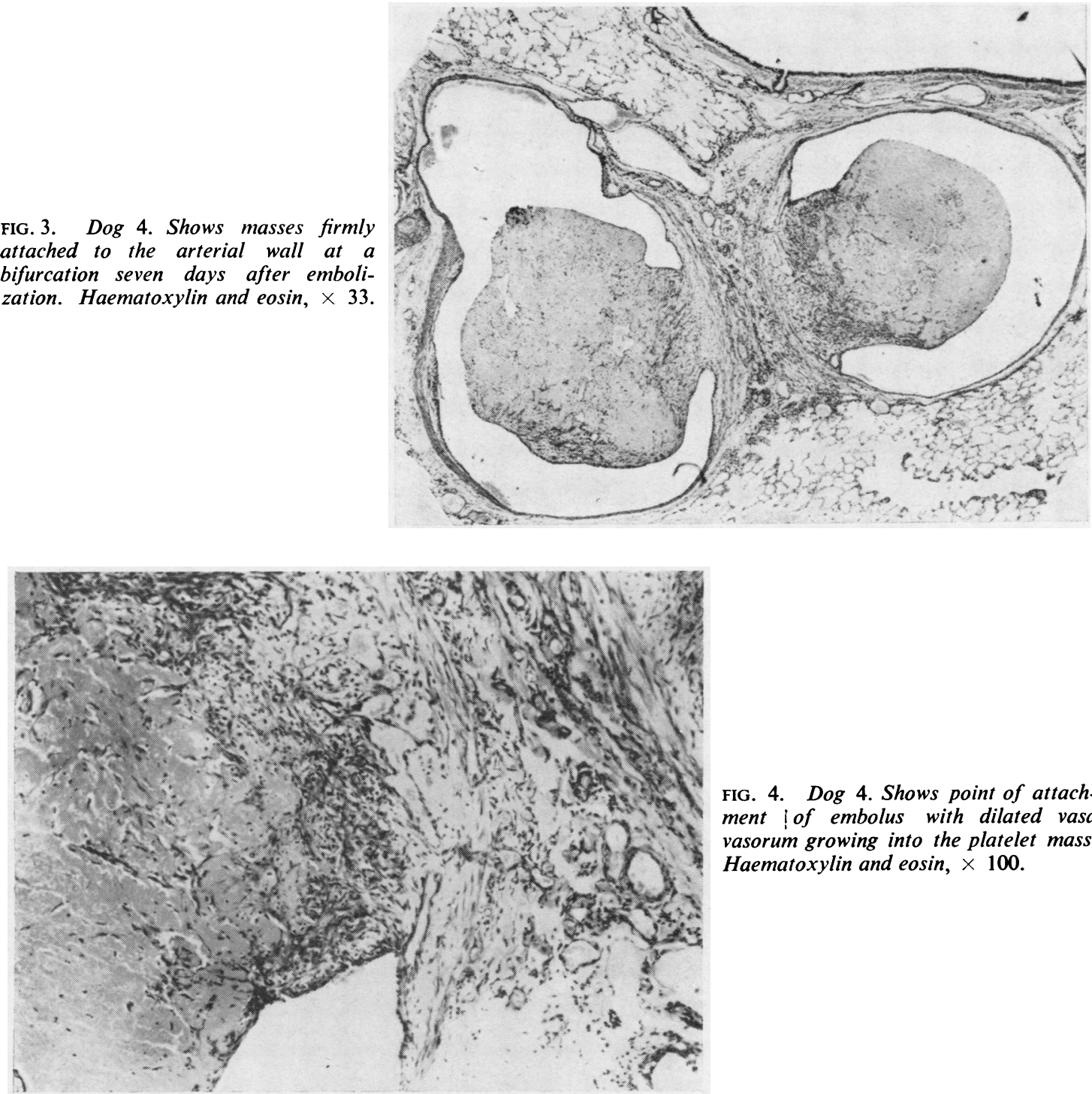

FIG. 4. Dog 4. Shows point of attachment of embolus with dilated vasa vasorum growing into the platelet mass. Haematoxylin and eosin, $\times 100$.

growing through the arterial wall and penetrating the embolus, accompanied by numerous fibroblasts. In the main body of the embolus numerous small irregular-shaped vascular channels were being formed (Fig. 5).

The appearances in dog 5 were interesting, since two sets of emboli were given a week apart and the animal was killed on the same day as the second experiment. Figure 6 shows a small conducting artery with the embolus lodged at a bifurcation. The material in the vessel can be seen to contain two components. The more darkly staining material is the organizing, seven-day-old embolus, while the more lightly staining material is composed of the recently injected platelet agglutinates.

\section{LONG-TERM EXPERIMENTS}

General effects Throughout the long-term experiments there were no general adverse effects on the dogs, which remained healthy and active in spite of weekly anaesthesia. 


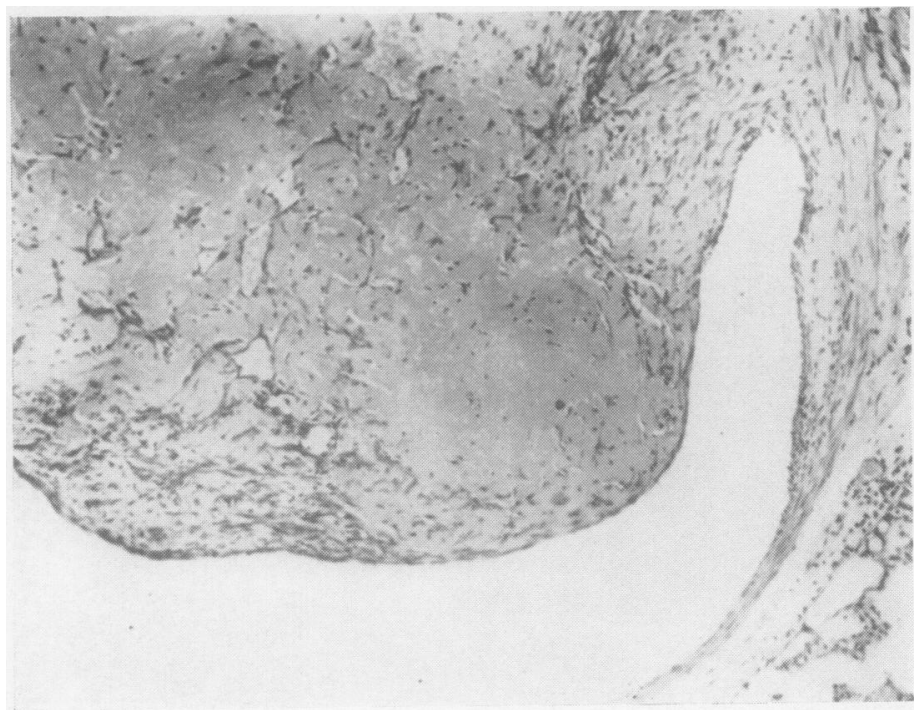

FIG. 5. Dog 4. Vascular channels in the main body of the mass. The endothelium covering the organizing embolus can be seen. Haematoxylin and eosin, $\times 100$.

Haemodynamic effects These are shown in Table II. In some instances the catheter could not be introduced into the pulmonary artery, and in such cases the right ventricular pressures are shown.

Lung volumes and diffusing capacity The results of these measurements are shown in Table III. The lung volume increased in all dogs throughout the period of the experiment. The diffusing capacity also showed considerable increases. One of the dogs (dog 11) was young at the start of the experiment and the lung size might have increased through normal growth during the course of the experiment, but in none of the other dogs was there any obvious increase in body size. Unfortunately the dogs were not reweighed at the end of the experiment, but, owing to possible changes of body fat and muscle, total body weight would have been a poor guide to change in body size. In the four dogs $8,9,10$, and 11 , not only did the diffusing capacity increase but the diffusing capacity per unit lung volume also increased. This increase in diffusing capacity is in contrast to the results obtained in a previous series of dogs (Marshall et al., 1963), in which the diffusing capacity was
FIG. 6. Dog 5. Shows embolus lying astride a bifurcation. The more darkly staining material is the older embolus. Periodic acid Schiff, $\times 30$.

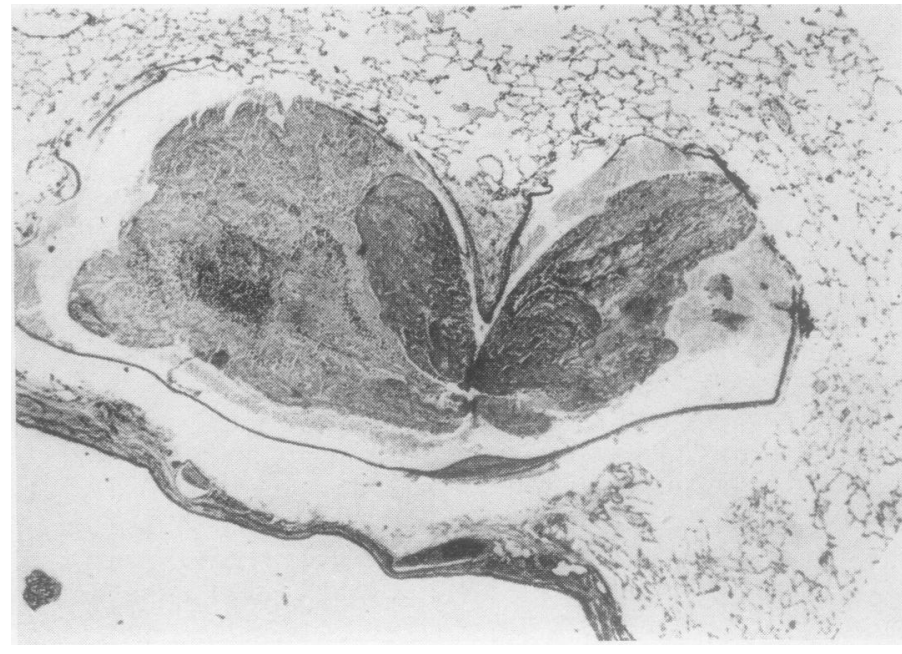


T A B L E II

HAEMODYNAMIC AND OTHER MEASUREMENTS BEFORE AND AFTER REPEATED INJECTIONS OF PLATELET AGGLUTINATES

\begin{tabular}{|c|c|c|c|c|c|c|c|}
\hline \multirow[b]{2}{*}{ Dog No. } & \multicolumn{3}{|c|}{$\begin{array}{l}\text { Pulmonary Art. } \\
\text { Press. (mm. Hg) }\end{array}$} & \multirow{2}{*}{$\begin{array}{l}\text { End- } \\
\text { tidal } \\
\text { PCO, }_{2} \\
\left(\mathrm{~mm}^{\text {Hg) }}\right.\end{array}$} & \multirow{2}{*}{$\begin{array}{c}\text { Arterial } \\
\text { Pco, } \\
\text { (mm. } \\
\mathbf{H g} \text { ) }\end{array}$} & \multirow{2}{*}{$\begin{array}{c}\text { End- } \\
\text { tidal- } \\
\text { arterial } \\
\mathrm{Pco}_{2} \\
(\mathrm{~mm} . \\
\mathrm{Hg})\end{array}$} & \multirow[b]{2}{*}{$\begin{array}{l}\text { R-to-I } \\
\text { Shunt } \\
(\%)\end{array}$} \\
\hline & Before & $\begin{array}{c}\text { Max. } \\
\text { after } \\
\text { Plate- } \\
\text { lets }\end{array}$ & $\begin{array}{l}\text { At } \\
\text { End }\end{array}$ & & & & \\
\hline $\begin{array}{l}\text { 8. Initial } \\
\text { Inject. } 10 \\
\text { Final } \ldots \\
\end{array}$ & \begin{tabular}{|l|}
$12 / 0$ \\
$7 / 1$ \\
$46 / 0$ \\
\end{tabular} & $\begin{array}{l}14: 0 \\
75 / 32\end{array}$ & $11 / 5$ & $\begin{array}{l}37.9 \\
57.1 \\
58.8\end{array}$ & 60.9 & $2 \cdot 1$ & $\begin{array}{l}5 \cdot 2 \\
9 \cdot 5 \\
3 \cdot 1\end{array}$ \\
\hline $\begin{array}{l}\text { 9. Initial } \\
\text { Inject. } 10 \\
\text { Final .. }\end{array}$ & $\begin{array}{c}14 / 2^{1} \\
9 / 2 \\
25 /-5\end{array}$ & $\begin{array}{l}16 / 3^{1} \\
15 / 2\end{array}$ & $\begin{array}{l}16 / 3^{1} \\
9 / 2\end{array}$ & $\begin{array}{l}46.5 \\
52.0 \\
52.5\end{array}$ & $55 \cdot 4$ & $2 \cdot 9$ & $\begin{array}{l}6 \cdot 7 \\
4 \cdot 5 \\
5 \cdot 2\end{array}$ \\
\hline $\begin{array}{l}\text { 10. Initial } \\
\text { Final }\end{array}$ & $\begin{array}{l}17 /-1^{1} \\
26 / 5 ; \\
31 /-5^{1}\end{array}$ & $20 /-2^{1}$ & $22 /-31$ & $\begin{array}{l}49.6 \\
52.0\end{array}$ & $\begin{array}{l}56 \cdot 0 \\
61 \cdot 1\end{array}$ & $\begin{array}{l}6 \cdot 4 \\
9 \cdot 1\end{array}$ & $\begin{array}{l}4 \cdot 1 \\
7 \cdot 0\end{array}$ \\
\hline 11. Initial & $\begin{array}{l}12 /-4 \\
23 / 0 ; \\
32 /-41\end{array}$ & $35 / 14$ & $15 /-1$ & $\begin{array}{l}49 \cdot 6 \\
55 \cdot 2\end{array}$ & $\begin{array}{l}57 \cdot 0 \\
61 \cdot 4\end{array}$ & $\begin{array}{l}7 \cdot 4 \\
6 \cdot 2\end{array}$ & $\begin{array}{l}9 \cdot 7 \\
6 \cdot 8\end{array}$ \\
\hline $\begin{array}{l}\text { 12. Initial } \\
\text { Final }\end{array}$ & $\begin{array}{l}10 ' 4 \\
22: 0\end{array}$ & $26 / 0$ & & $49 \cdot 3$ & $57 \cdot 2$ & $7 \cdot 9$ & 0 \\
\hline
\end{tabular}

${ }^{1}$ Right ventricular pressures.

T A B LE II I

EFFECT OF REPEATED PULMONARY EMBOLISM BY PLATELET AGGLUTINATES ON F.R.C. AND DLco

\begin{tabular}{|c|c|c|c|c|c|}
\hline Dog No. & $\begin{array}{c}\text { Weight } \\
\text { (kg.) }\end{array}$ & $\underset{\text { (ml.) }}{\text { F.R.C. }}$ & $\begin{array}{l}\text { F.R.C./ } \\
\text { kg. }\end{array}$ & $\begin{array}{c}\text { DLeo } \\
\text { (ml./min.' } \\
\text { mm. Hg) }\end{array}$ & $\begin{array}{l}\text { Duco/1. } \\
\text { F.R.C. }\end{array}$ \\
\hline $\begin{array}{l}\text { 8. Initial io } \\
\text { Inject. i0 } \\
\text { Inject. 20 } \\
\text { Final (43 } \\
\text { injections) }\end{array}$ & $13 \cdot 0$ & $\begin{array}{l}406 \\
569 \\
658 \\
673\end{array}$ & $31 \cdot 2$ & $\begin{array}{l}3.77 \\
7 \cdot 00 \\
7 \cdot 38 \\
9 \cdot 73 \\
\end{array}$ & $\begin{array}{r}9 \cdot 28 \\
12 \cdot 30 \\
11 \cdot 22 \\
14 \cdot 46 \\
\end{array}$ \\
\hline $\begin{array}{l}\text { 9. Initial } \\
\text { Inject. 10 } \\
\text { Inject. 20 } \\
\text { Final (42 } \\
\text { injections) }\end{array}$ & $9 \cdot 6$ & $\begin{array}{l}278 \\
419 \\
455 \\
474\end{array}$ & $29 \cdot 0$ & $\begin{array}{l}2 \cdot 30 \\
3 \cdot 60 \\
4 \cdot 60 \\
5 \cdot 46\end{array}$ & $\begin{array}{r}8 \cdot 28 \\
8 \cdot 59 \\
10 \cdot 11 \\
11 \cdot 52\end{array}$ \\
\hline $\begin{array}{l}\text { 10. Initial io } \\
\text { Inject. io } \\
\text { Final (29 } \\
\text { injections) }\end{array}$ & 11.9 & $\begin{array}{l}644 \\
680 \\
798\end{array}$ & $54 \cdot 2$ & $\begin{array}{l}4 \cdot 71 \\
5 \cdot 65 \\
6 \cdot 89\end{array}$ & $\begin{array}{l}7 \cdot 32 \\
8 \cdot 31 \\
8 \cdot 64\end{array}$ \\
\hline $\begin{array}{l}1 \text { Initial } \\
\text { Inject. 10 } \\
\text { Final (27 } \\
\text { injections) }\end{array}$ & $8 \cdot 2$ & $\begin{array}{l}305 \\
359 \\
582 \\
\end{array}$ & $37 \cdot 2$ & $\begin{array}{l}4 \cdot 25 \\
5.07 \\
7.64 \\
\end{array}$ & $\begin{array}{l}13 \cdot 95 \\
14 \cdot 10 \\
13 \cdot 12 \\
\end{array}$ \\
\hline $\begin{array}{l}\text { 12. Initial } \\
\text { Final (14 } \\
\text { injections) }\end{array}$ & $11 \cdot 0$ & $\begin{array}{l}221 \\
278\end{array}$ & $20 \cdot 1$ & $\begin{array}{l}5 \cdot 31 \\
5 \cdot 58\end{array}$ & $\begin{array}{l}24 \cdot 0 \\
20 \cdot 1\end{array}$ \\
\hline
\end{tabular}

lower in later measurements during the control period.

Effect on resp ration Table IV summarizes the effect of the emboli on respiration and respiratory mechanics. The change in non-elastic resistance has been calculated only in selected instances.

A well-marked response to embolization consisted of a period of rapid shallow breathing extending over 30 to 60 seconds. The weaker responses consisted in a reduction in tidal volume, often with no change in rate or, in some cases, a short period of apnoea.

In the earlier experiments of the series the yield of platelets was estimated as poor, moderate, or good from the size of the deposit before agglutination. The respiratory response bore no relationship to the yield of platelets estimated in this way. In the later experiments the platelet yield was counted and an assay was also made of the serotonin content of the platelets. The results are shown in Table V. Measurements were also made of the serotonin content of the agglutinates, of the supernatant fluid left after the agglutination of the platelets, and of the serum used to agglutinate

\section{T A B L E I V}

EFFECT OF EMBOLI OF PLATELET AGGREGATES ON THE RESPIRATORY PATTERN, ELASTIC RESISTANCE AND NON-ELASTIC RESISTANCE OF THE LUNGS OF DOG 81

\begin{tabular}{|c|c|c|c|c|}
\hline \multirow{2}{*}{$\begin{array}{c}\text { Embolus } \\
\text { No. }\end{array}$} & \multicolumn{2}{|c|}{ Respiratory Change } & \multirow{2}{*}{$\begin{array}{c}\text { Elastic } \\
\text { Resistance } \\
\text { (increase \%) }\end{array}$} & \multirow{2}{*}{$\begin{array}{c}\text { Non-elastic } \\
\text { Resistance } \\
\text { (increase \%) }\end{array}$} \\
\hline & Normal & Anoxic & & \\
\hline $\begin{array}{r}1 \\
2 \\
3 \\
4 \\
5 \\
6 \\
7 \\
8 \\
9 \\
10 \\
11 \\
12 \\
13 \\
14 \\
15 \\
16 \\
17 \\
18 \\
19 \\
20 \\
21 \\
22 \\
23 \\
24 \\
25 \\
26 \\
27 \\
28 \\
29 \\
30 \\
31 \\
32 \\
33 \\
34 \\
35 \\
36 \\
37 \\
38 \\
39 \\
40 \\
41 \\
42 \\
43\end{array}$ & $\begin{array}{c}0 \\
+ \\
0 \\
\pm \\
\pm \\
0 \\
0 \\
\pm \\
+++ \\
++ \\
++ \\
0 \\
\pm \\
0 \\
0 \\
0 \\
0 \\
0 \\
+ \\
\pm \\
\pm \\
\pm \\
0 \\
\pm \\
\pm \\
\pm \\
0 \\
0 \\
0 \\
0 \\
0 \\
0 \\
0 \\
0 \\
0 \\
+2 \\
03\end{array}$ & $\begin{array}{l}+ \\
+ \\
0 \\
+ \\
+ \\
+^{2} \\
0 \\
\pm\end{array}$ & $\begin{array}{r}0 \\
18 \\
0 \\
0 \\
0 \\
0 \\
400 \\
90 \\
140 \\
0 \\
0 \\
0 \\
0 \\
0 \\
0 \\
0 \\
50 \\
0 \\
21 \\
0 \\
0 \\
0 \\
23 \\
18 \\
0 \\
0 \\
0 \\
0 \\
0 \\
\\
0 \\
0 \\
0 \\
0 \\
0 \\
0 \\
20 \\
0 \\
30 \\
32 \\
0\end{array}$ & $\begin{array}{c}\text { Infinite } \\
180 \\
25\end{array}$ \\
\hline
\end{tabular}

The respiratory change of rapid, shallow breathing is graded as 0 , no change; \pm , slight change;,+++ , and +++ , increasing degrees of change.

${ }^{1}$ The results in dogs 9-11 were similar to those in dog 8. Further details may be obtained from the authors.

3 Previous serotonin infusion.
3 After treatment with reserpine. 
T A B LE V

RESULTS OF PLATELET COUNTS AND SEROTONIN ASSAYS ON THE PLATELET CONCENTRATE DILUTED TO A VOLUME OF $10 \mathrm{ml}$.

\begin{tabular}{|c|c|c|c|c|c|c|}
\hline \multirow{2}{*}{$\begin{array}{l}\text { Dog } \\
\text { No. }\end{array}$} & \multirow{2}{*}{$\begin{array}{c}\text { Embolus } \\
\text { No. }\end{array}$} & \multirow{2}{*}{$\begin{array}{l}\text { Platelets } \\
\text { c.mm. }\end{array}$} & \multirow{2}{*}{$\begin{array}{c}\text { Sero- } \\
\text { tonin } \\
(\mu \mathrm{g} . \mathrm{ml} .)\end{array}$} & \multicolumn{2}{|c|}{$\begin{array}{c}\text { Respiratory } \\
\text { Change }\end{array}$} & \multirow{2}{*}{$\begin{array}{c}\text { Elastic } \\
\text { Resistance } \\
\text { (increase } \\
\% \text { ) }\end{array}$} \\
\hline & & & & Normal & Anoxic & \\
\hline 8 & $\begin{array}{l}38 \\
39 \\
40 \\
41 \\
42 \\
43 \\
44\end{array}$ & $\begin{array}{l}960,000 \\
844,000 \\
515,000 \\
742,000 \\
824,000 \\
708,000 \\
604,000\end{array}$ & $\begin{array}{c}5 \cdot 0 \\
8 \cdot 5^{2} \\
16 \cdot 0^{2} \\
0^{3} \\
0 \cdot 8 \\
3 \cdot 3 \\
2 \cdot 1\end{array}$ & $\begin{array}{c}0 \\
+2 \\
0^{3}\end{array}$ & $\begin{array}{c}\mathbf{0} \\
\therefore\end{array}$ & $\begin{array}{r}0 \\
20 \\
0 \\
30 \\
32 \\
0\end{array}$ \\
\hline 9 & $\begin{array}{l}38 \\
39 \\
40 \\
41 \\
42 \\
43\end{array}$ & $\begin{array}{r}830,000 \\
1,370,000 \\
1,515,000 \\
1,381,000 \\
838,000 \\
964,000\end{array}$ & $\begin{array}{c}12 \cdot 5^{2} \\
20 \cdot 0^{2} \\
0^{3} \\
3 \cdot 6 \\
4 \cdot 3 \\
1 \cdot 8\end{array}$ & $+^{2}$ & $\begin{array}{l}+^{2} \\
0^{3} \\
+ \\
+\end{array}$ & $\begin{array}{r}50 \\
0 \\
0 \\
15 \\
0\end{array}$ \\
\hline 10 & $\begin{array}{l}25 \\
26 \\
27 \\
28 \\
29\end{array}$ & $\begin{array}{r}609,000 \\
690,000 \\
806,000 \\
1,120,000 \\
771,000\end{array}$ & $\begin{array}{c}3 \cdot 0 \\
9 \cdot 5^{2} \\
11 \cdot 5^{2} \\
3 \cdot 0^{2} \\
0 \cdot 5^{3}\end{array}$ & $\begin{array}{l}0 \\
0^{2}\end{array}$ & $\begin{array}{l}+2 \\
\div 0^{3}\end{array}$ & $\begin{array}{l}0 \\
0 \\
0 \\
0 \\
0\end{array}$ \\
\hline 11 & $\begin{array}{l}23 \\
24 \\
25 \\
26 \\
27\end{array}$ & $\begin{array}{r}1,043,000 \\
880,000 \\
725,000 \\
738,000 \\
665,000 \\
\end{array}$ & $\begin{array}{c}4 \cdot 5 \\
8 \cdot 5^{2} \\
13 \cdot 0^{2} \\
3 \cdot 0^{2} \\
0 \cdot 3^{3}\end{array}$ & $0^{2}$ & $\begin{array}{l}\because \\
\therefore 2 \\
\because{ }^{2} \\
0^{3}\end{array}$ & $\begin{array}{l}0 \\
0 \\
0 \\
0 \\
0\end{array}$ \\
\hline
\end{tabular}

The explanation of the symbols used is given under Table IV.

the platelets. The results of these measurements are shown in Table VI. Measurements were made on an additional $\operatorname{dog} \mathrm{A}$ because the measurements on the whole blood and plasma of dogs 8 to 11 were made invalid by the presence of EDTA. Heparin was used as an anticoagulant in dog $\mathrm{A}$. Heparin was added to the serum before agglutination of the platelets in some instances to see if heparin, by its antithrombin effect, would diminish the release of serotonin during agglutination. Also, in two instances, the serum was obtained from blood clotted in the presence of epsilon-amino- caproic acid in case the by-products of fibrinolysis influenced the release of serotonin. It can be seen $\overline{0}$ that an appreciable quantity of serotonin has bien lost from the platelets by the process of agglutination. Heparin and epsilon-aminocaproic acid had no effect on the release of serotonin. The serum used to agglutinate also contains an appreciable quantity of serotonin liberated from platelets during clotting of the blood. When injections of serum alone were given to the dogs there was no effect on respiration. The dose of serotonin which would be given in the fluid surrounding the agglutinates was usually of the order of 20 to $40 \mu \mathrm{g}$., and this dose, given as a solution of serotonin creatinine sulphate, was too small to produce any respiratory effect in these dogs.

The response to platelet embolization was much more consistent when the dogs were anoxic. Under these conditions the dogs were breathing rapidly before the injection of platelets, and the effect of embolization was usually to cause a short period of apnoea and to reduce the tidal volume. In order to investigate the possible apnoeic effect on an anoxic dog of an injection of $10 \mathrm{ml}$. of fluid with an oxygen tension of about $200 \mathrm{~mm}$. $\mathrm{Hg}$ (such as the platelet suspension would have at $37^{\circ} \mathrm{C}$.), control injections of saline were given. These had no effect on the respiration.

Effect of injections of serotonin and histamine The effect of these drugs on the pattern of breathing is summarized in Table VII. Histamine usually caused rapid shallow respiration as compared with the transient increase in respiratory depth usually produced by serotonin (Fig. 7). With doses of the order of 100 to $200 \mu \mathrm{g}$. serotonin creatinine sulphate and 50 to $100 \mu \mathrm{g}$. histamine acid phos-

T A B L E V I

SEROTONIN CONTENT OF PLATELET CONCENTRATES BEFORE AND AFTER AGGLUTINATION

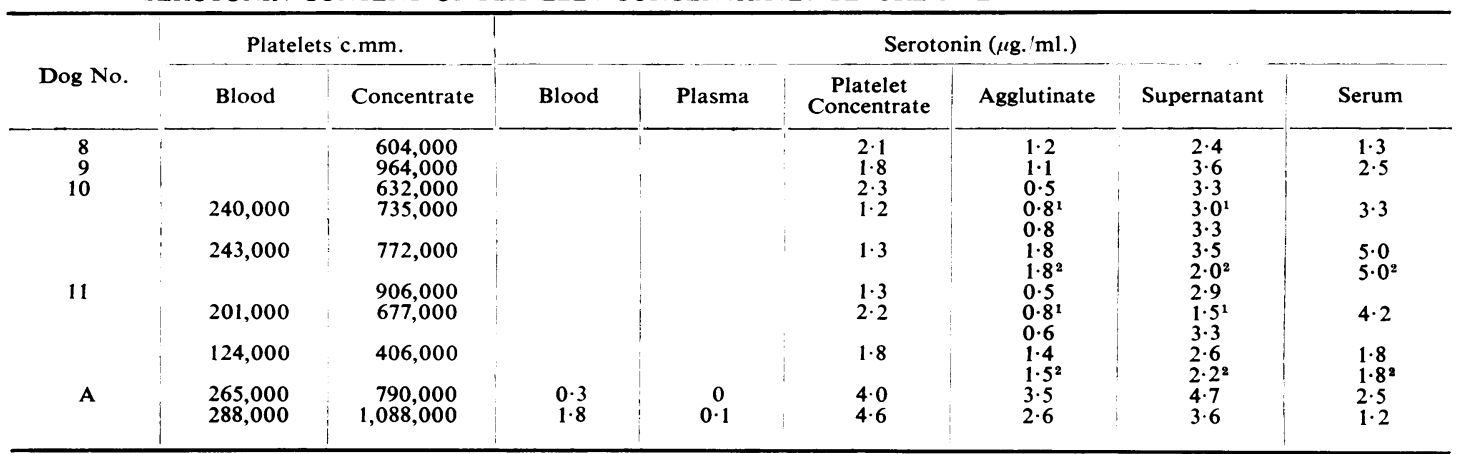

1 Heparin added to serum before agglutination.

2 Serum from blood clotted in the presence of epsilon-aminocaproic acid.

The measurements were made after the total platelet concentrate from $80 \mathrm{ml}$. of blood had been diluted to $10 \mathrm{ml}$. 
T AB LE VII

SUMMARY OF THE EFFECTS OF SEROTONIN AND HISTAMINE ON THE PATTERN OF RESPIRATION

\begin{tabular}{|c|c|c|c|c|}
\hline \multirow{2}{*}{ Dog No. } & \multicolumn{2}{|c|}{ Serotonin } & \multicolumn{2}{|c|}{ Histamine } \\
\hline & $100 \mu \mathrm{g}$ & $200 \mu \mathrm{g}$ & $50 \mu \mathrm{g}$ & $100 \mu \mathrm{g}$. \\
\hline 8. $\begin{array}{l}\text { Normal } \\
\text { Anoxic }\end{array}$ & $\begin{array}{l}0 \\
\text { c }\end{array}$ & $\begin{array}{l}\text { c } \\
\text { c }\end{array}$ & $\begin{array}{l}b- \\
b\end{array}$ & \\
\hline 9. $\begin{array}{l}\text { Normal } \\
\text { Anoxic }\end{array}$ & $\begin{array}{l}0 \\
\text { c }\end{array}$ & $\begin{array}{l}0 \\
c+\end{array}$ & $\begin{array}{l}\mathbf{b} \\
\mathbf{b}\end{array}$ & $\begin{array}{l}\mathbf{b} \\
\mathbf{b}\end{array}$ \\
\hline 10. $\begin{array}{l}\text { Normal } \\
\text { Anoxic }\end{array}$ & $\begin{array}{l}0 \\
b \text { or c }\end{array}$ & $\begin{array}{l}c- \\
c+\end{array}$ & $\begin{array}{l}0 \\
b-\end{array}$ & $\begin{array}{l}\mathbf{b}- \\
\mathbf{b}\end{array}$ \\
\hline 11. $\begin{array}{l}\text { Normal } \\
\text { Anoxic }\end{array}$ & $\begin{array}{l}0 \\
\text { c }\end{array}$ & $\begin{array}{l}c \\
c+\end{array}$ & $\begin{array}{l}b- \\
b\end{array}$ & $\begin{array}{l}\mathbf{b} \\
\mathbf{b}+\end{array}$ \\
\hline 12. $\begin{array}{l}\text { Normal } \\
\text { Anoxic }\end{array}$ & $\begin{array}{l}0 \\
\text { c }\end{array}$ & $\begin{array}{l}\mathrm{c}- \\
\mathrm{c}\end{array}$ & $\begin{array}{c}\mathbf{b} \text { or } \mathbf{c} \\
\mathbf{b}\end{array}$ & b \\
\hline
\end{tabular}

$0=$ no effect.

$\mathbf{b}=$ rapid shallow breathing.

$c=$ increased depth of breathing.

+ indicates a marked response, and

- a weak response.

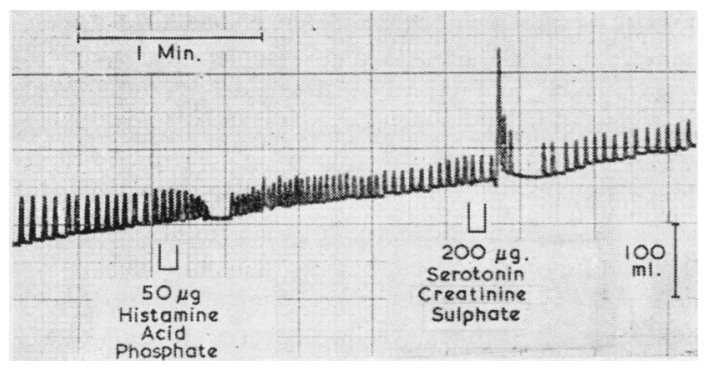

FIG. 7. Dog 12. Characteristic respiratory reponses to histamine and serotonin.

phate there were usually no, or only small, increases of non-elastic resistance. This was in marked contrast to the large increase in nonelastic resistance which occurred during the infusion of serotonin at a rate of $1 \mathrm{mg}$. $/$ minute.

Histological examination In these dogs histological examination showed no platelet emboli and no change in the thickness or composition of the arterial walls to account for the systolic pulmonary hypertension which was observed clinically. Dog 10 showed diffuse enlargement of the air spaces amounting to pan-lobular emphysema. This change, however, was probably present before the start of the experiment, because in this dog the functional residual capacity of the lungs per kilogram body weight was almost twice as high as in the other dogs (Table III). Dogs 8, 9, and 11 showed only marginal emphysema, such as is commonly found in dogs, and the lungs of dog 12 were normal.

\section{DISCUSSION}

The reasons for carrying out the short-term experiments were, first, to see what effect platelet emboli had on pulmonary haemodynamics, and, secondly, to see the histological picture of platelet emboli. The experiments showed that platelet emboli, in the fairly large doses given in some of these experiments, could cause an increase in pulmonary arterial pressure and a change in respiratory rhythm. These experiments also showed that emboli of platelet agglutinates, whether agglutinated by ADP or by autologous serum, did not always disintegrate but could persist in the pulmonary vessels and eventually become organized.

At the start of this series of experiments it was hoped that embolization by platelet agglutinates might give a consistent response so that the effect of modifying factors could be assessed. In practice, the immediate respiratory response to embolization was often absent, and it was only under the influence of anoxia that anything resembling a consistent response was obtained.

A very strong response to embolization was obtained in $\operatorname{dog} 8$ during emboli numbers 9,10 , and 11. Embolus 9 caused such strong bronchoconstriction that complete bronchial occlusion occurred and large fluctuations in intrapleural pressure produced no tidal volume. The increase in pulmonary arterial pressure caused by the tenth embolus in this dog was also much larger than in any other instance in which pulmonary arterial pressure was measured. At about the time of the ninth embolus the dog had a cough and it was thought that the strong response might be related to bronchial infection. A few weeks later, however, dog 9 had a cough and the response to embolization was no different from usual. It is of interest that Severinghaus, Swenson, Finley, Lategola, and Williams (1961) suggested that intestinal or respiratory infections in their dogs might be a factor in determining the degree of response to unilateral pulmonary artery occlusion.

The variable response to platelet emboli could not be explained by the serotonin content of the platelets before agglutination. Measurements were made on the agglutinates in some of the later experiments. The experiments on the increase of serotonin content of the platelets by previous infusion of serotonin and reduction of serotonin content by treatment with reserpine (Tables IV and $V$ ) suggest that the serotonin content of the platelets may have some effect on the magnitude of the response, but, in view of the variability of 
the results, the number of experiments carried out was too small for a definite conclusion to be reached. Further experiments have been carried out on the effect of embolization with small blood clots depleted of serotonin; these have been reported separately (Marshall, 1966).

A change in respiratory rhythm after embolization was not always accompanied by a change in compliance or non-elastic resistance, and the shallow breaths were usually the result of a smaller swing of intrathoracic pressure and were presumably due to a diminished stimulus from the respiratory centre. The deeper breaths seen after small doses of serotonin and the rapid shallow breathing seen after small doses of histamine also were often not accompanied by any change in compliance or non-elastic resistance, so it seems probable that these drugs in small doses produce their effect by modifying the output of the respiratory centre either directly or indirectly (Mott and Paintal, 1953). The respiratory response to platelet emboli was much more like the response to histamine than to the effect of serotonin. If the response is due to histamine it must be due to histamine liberated from the lung tissue in response to the embolization and not to histamine released from the platelets. Dog platelets contain no histamine (Humphrey and Jaques, 1954), but serotonin has the power to liberate histamine from tissues (Feldberg and Smith, 1953).

The platelet concentrates and serum used in these experiments were also assayed on guinea-pig ileum previously treated with methysergide to inhibit serotonin. The ileum did not respond to the platelet concentrates or serum but it contracted strongly with histamine.

Whole blood contains only about $2 \mu \mathrm{g}$. serotonin per $\mathrm{ml}$. and most of this resides in the platelets. When blood clots, most of the serotonin is released by thrombin and other factors (Zucker and Borrelli, 1955) and so the serotonin content of the clot is even smaller. A clot of $20 \mathrm{ml}$. in volume may contain only about $40 \mu \mathrm{g}$. serotonin. This quantity of serotonin injected into the pulmonary arteries of dogs usually produces no respiratory response even when it is injected into an occluded artery (Marshall, unpublished observations). Rose and Lazaro (1958) did find such small doses produced a rise in pulmonary vascular resistance in some dogs but no bronchomotor effects. Doses of up to $300 \mu \mathrm{g}$. $/ \mathrm{kg}$. given intravenously had little effect on the cardiovascular system in 44 out of 50 conscious or anaesthetized patients investigated by Stone, Horiguchi, Donnelly, and Nemir (1961). Michel- son, Hollander, and Lowell (1958), also using doses of 0.5 to $1.5 \mathrm{mg}$., found hyperventilation but no bronchoconstriction even in asthmatic subjects. The systemic blood pressure was not measured, but these subjects had no symptoms suggesting that it fell. The serotonin content of blood may increase twofold after operation, but $\vec{O}$ even this increase is not likely to produce a clot with a serotonin content high enough to cause vasomotor or bronchomotor changes.

Medium-sized and large emboli impact in $\vec{x}$ vessels which are themselves unresponsive to 곤 embolization (Marshall et al., 1963). For serotonin is liberated from such emboli to be effective it must act on the vessel wall, initiating a reflex which $N$ causes broncho-constriction and possibly pul- 은 monary artery constriction.

No evidence was found for the presence in $\operatorname{dog} \subseteq$ blood or platelets of any active substance other than serotonin. When tested on guinea-pig ileum, $\vec{\oplus}$ methysergide inhibited the response to serotonin, platelets, and serum, but the preparation still responded to histamine. Promethazine inhibited the response to serotonin, histamine, platelets, and whole blood, but the preparation still responded to bradykinin.

The static compliance of the lungs and chest wall measured on each dog at the start of each week's experiment showed some week-to-week variation, but there was no appreciable change in compliance throughout the series except possibly in $\operatorname{dog} 11$, in which there was a slight increase. The dynamic compliance of the lungs also showed no appreciable change throughout this time.

The systolic pulmonary arterial pressure had increased in all dogs at the end of the series of platelet injections. The systolic pressure was only moderately raised, but it was significantly higher than the systolic pulmonary arterial pressure measured in a series of 40 normal dogs under similar conditions and anaesthesia (mean $12.4 \mathrm{~mm}$. $\mathrm{Hg}$, S.D. $\pm 4 \cdot 7$ ). On the other hand, the diastolic of pulmonary arterial pressure was not increased $N$ above the normal mean of $1 \cdot 1 \mathrm{~mm}$. Hg, S.D. $\pm 2 \cdot 3$. The heart rate in these dogs varied from 72 to 135 per minute, but there was no appreciable difference in the rates at the beginning and end of the series of injections.

The histology of the lung vessels in these dogs was normal and provided no explanation for the high systolic pulmonary arterial pressure, but it was presumably associated with a less distensible pulmonary vascular bed.

The increased diffusing capacity was due in part to the increase in the F.R.C. and in part to the 
increase in diffusing capacity per unit volume of lung. As mentioned earlier, it is impossible to be sure that in some of the dogs the lungs had not increased in size as a result of growth of the dogs but, except in one dog, increase in body size was not obvious. It seems probable that the F.R.C. had increased as a direct result of the pulmonary emboli, but the mechanism of increase was not apparent. The non-elastic resistance of the lungs did not show any consistent increase or decrease throughout the period of the experiment.

The increase in diffusing capacity per unit lung volume could probably be explained by an increase in the surface area of the capillaries in contact with the alveolar spaces. These capillaries, when fully dilated, occupy most of the surface of the alveolus (Weibel, 1963), but it is probable that they are normally not all open together (von Hayek, 1960 ; Staub and Storey, 1962). The effect of chronic obstruction to small arteries and arterioles and of the high systolic pulmonary arterial pressure may be to cause more of the capillaries to remain open. Heath (1959) has described dilatation of arteriolar branches of occluded pulmonary arteries, proximal or distal to the obstruction, and these may form a plexiform mass giving off capillaries in the alveolar walls.

\section{SUMMARY}

Platelet agglutinates, formed by the action of adenosine diphosphate or by autologous serum, were injected intravenously in 12 dogs. Seven dogs were killed within seven days after only one or two injections of platelet agglutinates. Large doses of agglutinates caused a transient rise in pulmonary arterial pressure and a change in respiratory rhythm. The agglutinates could be found in the pulmonary arteries, and organization of the platelet emboli was observed by the seventh day.

To five dogs repeated injections of platelet agglutinates were given at weekly intervals for up to 43 weeks. These dogs developed mild pulmonary hypertension but were otherwise well, and at necropsy no pathological changes were found in the pulmonary vessels. The immediate response to the platelet emboli was variable, but was not related to the serotonin content of the platelets. The effect of the emboli on respiration was increased when the dogs were anoxic.

\section{REFERENCES}

Carstairs, K. C. (1965). The identification of platelets and platelet antigens in histological sections. J. Path. Bact., 90, 225.

Feldberg, W., and Smith, A. N. (1953). Release of histamine by tryptamine and 5-hydroxytryptamine. Brit. J. Pharmacol., 8, 406.

Haverback, B. J., Dutcher, T. F., Shore, P. A., Tomich, E. G., Terry, L. L., and Brodie, B. B. (1957). Serotonin changes in platelets and brain induced by small daily doses of reserpine. Lack of effect of depletion of platelet serotonin on hemostatic mechanisms. New Engl. J. Med., 256, 343.

von Hayek, H. (1960). The Human Lung. Translated by Krahl, V. E., p. 254. Hafner, New York.

Heath, D. (1959). Structural alterations of pulmonary vessels in response to pulmonary hypertension. In Pulmonary Circulation. Ed. Adams, W. R., and Veith, I., p. 122. Grune and Stratton, New York.

Humphrey, J. H., and Jaques, R. (1954). The histamine and serotonin content of the platelets and polymorphonuclear leucocytes of various species. J. Physiol. (Lond.), 124, 305.

- and Toh, C. C. (1954). Absorption of serotonin (5-hydroxytryptamine) and histamine by dog platelets. Ibid., 124, 300 .

Marshall, R. (1966). Serotonin and embolisation by small blood clots in dogs. Thorax, $21,266$.

and Allison, P. R. (1962). Pulmonary embolism by small blood clots. Ibid., 17, 289.

Sabiston, D. C., Allison, P. R., Bosman, A. R., and Dunnill, M. S. (1963). Immediate and late effects of pulmonary embolism by large thrombi in dogs. Ibid., 18, 1 .

Michelson, A. L., Hollander, W., and Lowell, F. C. (1958). The effect of 5 -hydroxytryptamine (serotonin) on the respiration of nonasthmatic and asthmatic subjects. J. Lab. clin. Med., 51, 57.

Mott, J. C., and Paintal, A. S. (1953). The action of 5-hydroxytryptamine on pulmonary and cardiovascular vagal afferent fibres and its reflex respiratory effects. Brit. J. Pharmacol., 8, 238.

Rose, J. C., and Lazaro, E. J. (1958). Pulmonary vascular responses to serotonin and effects of certain serotonin antagonists. Circulat. Res., 6, 283.

Severinghaus, J. W., Swenson, E. W., Finley, T. N., Lategola, M. T., and Williams, J. (1961). Unilateral hypoventilation produced in dogs by occluding one pulmonary artery. J. appl. Physiol., 16, 53.

Shore, P. A., Pletscher, A., Tomich, E. G., Carlsson, A., Kuntzman, R., and Brodie, B. B. (1957). Role of brain serotonin in reserpine action. Ann. N.Y. Acad. Sci., 66, 609.

Staub, N. C., and Storey, W. F. (1962). Relation between morphological and physiological events in lung studied by rapid freezing. J.appl.Physiol., 17, 381 .

Stone, H. H., Horiguchi, S., Donnelly, C. C., and Nemir, P. (1961). Changes in plasma serotonin concentration in the surgical patient : its possible significance. Surg. Forum, 12, 140.

Weibel, E. R. (1963). Morphometry of the Human Lung, pp. 78-110. Springer, Berlin.

Weissbach, H., Bogdanski, D. F., and Udenfriend, S. (1958). Binding of serotonin and other amines by blood platelets. Arch. Biochem., $73,492$.

Zucker, M. B., and Borrelli, J. (1955). Quantity, assay and release of serotonin in human platelets. J. appl. Physiol., 7, 425. 